\title{
OTIMIZAÇÃO DA IMUNOFLUORESCÊNCIA DIRETA PARA DIAGNÓSTICO DE RAIVA*
}

\author{
OPTIMIZATION OF THE DIRECT FLUORESCENT ANTIBODY TEST FOR \\ RABIES DIAGNOSIS
}

PAULO MICHEL ROEHE ${ }^{1,2}$, REJANE SCHAEFER ${ }^{1,3}$ \& ALEXANDRE DA SILVA PEREIRA ${ }^{1 \S}$

\begin{abstract}
RESUMO
O diagnóstico laboratorial da raiva utiliza uma metodologia padronizada, baseada essencialmente no método de imunofluorescência direta, ou "direct fluorescent antibody test" (DFAT). No presente estudo foram reavaliadas algumas variáveis do DFAT, incluindo a duração do tempo de fixação das lâminas com impressões de tecido nervoso, duração das incubações de pré-adsorção do conjugado com as suspensões de tecido nervoso de camundongos infectados (IMB) ou não infectados (NMB) e a duração do período de incubação destas misturas sobre as lâminas com as impressões fixadas. A combinação que proporcionou maior eficácia à DFAT foi obtida com a fixação das lâminas com impressões de tecido nervoso em acetona a $-20^{\circ} \mathrm{C}$ por 30 minutos, pré-adsorção do conjugado com suspensões de $\mathrm{NMB}$ e IMB por 60 minutos a $37^{\circ} \mathrm{C}$ e subseqüente incubação dessas misturas sobre as impressões por 2 horas a $37^{\circ} \mathrm{C}$. Estas alterações permitiram a obtenção de uma fluorescência de intensidade sensivelmente maior que a obtida com a metodologia padrão recomendada, aliada a uma completa inibição da fluorescência sobre os controles.
\end{abstract}

Descritores: raiva, diagnóstico, imunofluorescência, DFAT.

\begin{abstract}
Rabies diagnosis follows a standardized methodology, where the direct fluorescent antibody test (DFAT) plays an essential role. Optimization of DFAT procedures may improve sensitivity and specificity of the test. In the present study, some of the variables of DFAT were reassessed, such as the duration of acetone fixation of brain impressions on slides, incubation of the pre-adsorbing mixtures of conjugate and infected (IMB) and uninfected mouse brain suspensions (NMB), as well as the length of incubation of the pre-adsorbing mixtures on fixed brain impressions. The combination that provided the greatest efficacy at DFAT was attained when slides were fixed for 30 minutes in acetone at $-20^{\circ} \mathrm{C}$, the pre-adsorbing conjugate and $\mathrm{NMB} / \mathrm{IMB}$ suspensions were incubated for 60 minutes at $37^{\circ} \mathrm{C}$ and subsequently layered onto impressions for 2 hours at $37^{\circ} \mathrm{C}$. These modifications provided a more intense fluorescent reaction, together with a complete inhibition of fluorescence on the control impressions, when compared to the standard recommended procedure.
\end{abstract}

Key words: rabies, diagnosis, immunofluorescence, DFAT.

* Trabalho apoiado pelo PRONEX, CNPq, FAPERGS. ${ }^{1}$ Equipe de Virologia do Centro de Pesquisa Veterinária Desidério Finamor (EVICPVDF)- Fundação Estadual de Pesquisa Agropecuária (FEPAGRO). ${ }^{2}$ Laboratório de Virologia, Departamento de Microbiologia (DM), Instituto de Ciências Básicas da Saúde (ICBS) - UFRGS. ${ }^{3}$ Programa de Pós-Graduação em Ciências Veterinárias da Faculdade de Veterinária da UFRGS. §in memoriam.

CORRESPONDÊNCIA: P.M. Roehe [e-mail:proehe@orion.ufrgs.br ; FAX: +55 5148133 37] Virologia, Departamento de Microbiologia/ICBS UFRGS; Av. Sarmento Leite, 500; C.E.P. 90001-970 - Porto Alegre, RS - Brasil. 


\section{INTRODUÇÃO}

O diagnóstico laboratorial da raiva utiliza uma metodologia padronizada, baseada largamente na utilização da imunofluorescência direta (DFAT), usualmente em conjunto com a inoculação em camundongos lactentes ou cultivos celulares $[3,5]$. A despeito da emergência de métodos moleculares de diagnóstico [1,6,7], devido a sua alta sensibilidade e especificidade, a DFAT permanece até o presente como método padrão utilizado na maioria dos laboratórios para orientação de procedimentos a serem adotados em tratamentos pós-exposição. Dependendo do treinamento do pessoal de laboratório, a DFAT é capaz de detectar índices iguais ou superiores a $100 \%$ das amostras infectadas, se tomada como "padrão ouro" a inoculação em camundongos lactentes $[3,5]$.

A técnica padrão de DFAT para o diagnóstico de raiva recomenda que o conjugado isotiocianato de fluoresceína (FITC)/anticorpo anti-rábico policlonal específico, quando produzido a partir de vírus multiplicado em cérebro de camundongos, seja préadsorvido, à proporção de $1 / 5$, com uma suspensão de $20 \%$ de tecido nervoso de camundongos não infectados, denominada "cérebro de camundongo normal" (NMB).

Esta pré-adsorção tem como objetivo minimizar possíveis reações inespecíficas decorrentes da presença de tecido nervoso no imunógeno utilizado na imunização dos animais (usualmente cobaios ou coelhos) para o preparo do conjugado $[2,4]$. Quando esta suspensão é adicionada sobre uma lâmina com um esfregaço de tecido nervoso infectado, deverá permitir a visualização da fluorescência característica, indicativa da presença do antígeno viral.

Paralelamente, outra alíquota do conjugado é pré-adsorvida, na mesma proporção, a uma suspensão de tecido nervoso infectado com a amostra de vírus rábico padrão (IMB). Este passo tem a finalidade de proporcionar a inibição do conjugado, $\mathrm{o}$ qual deverá ser totalmente adsorvido ao antígeno viral presente na suspensão de tecido infectado. Assim, quando a suspensão contendo IMB for colocada sobre tecido infectado, não deverá ser observada fluorescência, evidenciando a especificidade da reação. Entretanto, para que a prova seja realizada com segurança, é fundamental que sejam utilizados reagentes corretamente padronizados e devidamente titulados.

Com base em observações efetuadas em outros testes de imunofluorescência, o presente estudo buscou reavaliar as seguintes variáveis: a) o tempo de fixação em acetona das lâminas com impressões de tecido nervoso; b) a duração do tempo de incubação da mistura de pré-adsorção do conjugado com as suspensões de tecido nervoso não infectados (NMB) e infectados (IMB); e c) o tempo de incubação das misturas pré-adsorvidas sobre as impressões fixadas.

\section{MATERIAIS E MÉTODOS}

Estoques de cérebro de camundongo infectado (IMB) foram preparados a partir da amostra CVS 31/2 do INPPAZ ${ }^{1}$. O conjugado utilizado foi obtido da BioManguinhos ${ }^{2}$.

A metodologia utilizada para o preparo e titulação dos reagentes seguiu essencialmente as normas preconizadas $[2,4]$. O esquema utilizado para o preparo, produção e leitura das lâminas igualmente seguiu recomendações padronizadas [2]. A préadsorção foi feita como segue: alíquotas de $0,4 \mathrm{ml}$ de NMB e IMB mantidas a $-20^{\circ} \mathrm{C}$ foram descongeladas e imediatamente misturadas com $0,1 \mathrm{ml}$ de conjugado previamente titulado (2) e incubados a $37^{\circ} \mathrm{C}$ por 5 , $15,30,60$ ou 90 minutos.

As lâminas com impressões de tecido nervoso infectado foram produzidas a partir de encéfalos de camundongos de 3 a 4 semanas de idade, infectados com a amostra CVS 31/2, nos quais foram inoculados aproximadamente 1000 doses infectantes 50\% ( ID $\left._{50}\right)$ para camundongos, por via intracerebral.

Duas impressões de cortes transversais de encéfalos dos mesmos foram preparadas em cada lâmina. A seguir, as mesmas foram fixadas por a) 30 minutos ou b) 4 horas em acetona a $-20^{\circ} \mathrm{C}$, secas à temperatura ambiente e as áreas dos impressões delimitadas com esmalte e estocadas a $-20{ }^{\circ} \mathrm{C}$.

Para a imunofluorescência, as mesmas foram colocadas à temperatura ambiente por 5 minutos e cobertas com $30 \mathrm{ml}$ de conjugado pré-adsorvido 
com NMB e IMB, respectivamente, em cada uma das impressões. A seguir, as mesmas foram incubadas por $30,60,90$ ou 120 minutos, sendo subseqüentemente lavadas com solução salina tamponada com fosfato (PBS, pH 8,5) e com um enxágüe final em água destilada. Após, as mesmas foram montadas com glicerol a $90 \%$ em PBS (pH $8,5)$ e cobertas com lamínula. A leitura foi feita em microscópio Axiolab (Zeiss) ${ }^{3}$, equipado com uma lâmpada de vapor de mercúrio HBO 50, com os filtros recomendados pelo fabricante, com aumento de $400 \mathrm{X}$.

A leitura foi avaliada de acordo com a intensidade de fluorescência observada na impressão coberta pela mistura $\mathrm{NMB} /$ conjugado, com base em uma escala subjetiva de intensidade, variando de "+" (fluorescência de baixa intensidade) a "++++" (fluorescência de alta intensidade). Os testes foram realizados em duas oportunidades distintas, com 2 grupos de lâminas fixadas a 30 minutos e 2 grupos fixados por 4 horas a $-20^{\circ} \mathrm{C}$ e submetidos às demais variáveis, sendo examinados independentemente por dois observadores experimentados. A intensidade de inibição foi igualmente avaliada com base em uma escala subjetiva, considerando-se a total inibição de fluorescência como " $100 \%$ ", em escala decrescente, de acordo com a intensidade da fluorescência observada.

\section{RESULTADOS}

Os resultados obtidos estão apresentados na Tabela 1. Quanto ao tempo de fixação das impressões nas lâminas em acetona, não foi observada diferença notável na qualidade da fluorescência obtida com impressões fixadas por 30 minutos ou 4 horas. Por outro lado, à medida em que o tempo de pré-adsorção $\mathrm{NMB} /$ conjugado e IMB/conjugado foi aumentado, ocorreu um aumento progressivo na inibição da fluorescência sobre as impressões controle.

Quando os tempos de incubação das misturas pré-adsorvidas sobre as impressões foram gradualmente aumentados, houve um aumento correspondente na intensidade da fluorescência, porém contraposto por uma diminuição na inibição

Tabela 1. Efeito da duração dos tempos de pré-adsorção e incubação sobre lâminas na imunofluorescência direta para a identificação antígenos do vírus da raiva.

\begin{tabular}{|c|c|c|c|c|c|}
\hline \multicolumn{2}{|c|}{$\begin{array}{l}\text { Tempo de } \\
\text { Pré-adsorção }\end{array}$} & \multicolumn{4}{|c|}{ Tempo de incubação e resultado da imunofluorescência direta } \\
\hline & & $30^{\prime}$ & $60^{\prime}$ & $90^{\prime}$ & $120^{\prime}$ \\
\hline \multirow[t]{2}{*}{5} & Positivo & $+@$ & ++ & +++ & ++++ \\
\hline & Inibição ${ }^{\S}$ & $100^{\S \S}$ & 100 & 90 & 90 \\
\hline \multirow[t]{2}{*}{$15^{\prime}$} & Positivo & + & ++ & +++ & ++++ \\
\hline & Inibição & 100 & 100 & 90 & 90 \\
\hline \multirow[t]{2}{*}{$30^{\prime}$} & Positivo & + & ++ & +++ & ++++ \\
\hline & Inibição & 100 & 100 & 95 & 95 \\
\hline \multirow[t]{2}{*}{$60^{\prime}$} & Positivo & + & ++ & +++ & ++++ \\
\hline & Inibição & 100 & 100 & 100 & 100 \\
\hline \multicolumn{6}{|c|}{$\begin{array}{l}\text { Intensidade de fluorescência; } \$ \text { Porcentual de inibição de fluorescência nos controles. } \\
\text { Refere-se ao par de impressões de tecido nervoso infectado nas lâminas em teste: } \\
\text { Positivo: impressão sobre a qual foi colocada a mistura pré-adsorvida de NMB/conjugado; Inibição: impressão } \\
\text { sobre a qual foi colocada a mistura pré-adsorvida de IMB/conjugado. }\end{array}$} \\
\hline
\end{tabular}


nas impressões de controle (Tabela 1).

Ao confrontar a intensidade de fluorescência com a intensidade de inibição da mesma, observou-se que a combinação que proporcionou melhor resultado na prova foi aquela em que as misturas de préadsorção $\mathrm{NMB} /$ conjugado e IMB/conjugado foram incubadas previamente por 60 minutos a $37^{\circ} \mathrm{C}$, sendo as mesmas posteriormente colocadas sobre as lâminas por um período de 2 horas a $37^{\circ} \mathrm{C}$ (Tabela 1 ).

Não foram observadas diferenças quanto à intensidade de fluorescência em impressões fixadas por períodos de 30 minutos ou 4 horas.

\section{DISCUSSÃO}

O prolongamento dos tempos de incubação na pré-adsorção (com as suspensões de NMB e IMB), como na incubação dessas sobre as impressões, permitiu a obtenção de uma fluorescência de alta intensidade, aliada a uma completa inibição sobre as impressões de controle.

Curiosamente, no procedimento padrão, o tempo de pré-adsorção, cuja importância foi aqui demonstrada, não havia sido definido [2,4]. Além disso, o período de incubação das misturas préadsorvidas sobre as lâminas foi, no protocolo original, fixado em 30 minutos a $37^{\circ} \mathrm{C}$. A pré-adsorção de 60 minutos a $37^{\circ} \mathrm{C}$, associada à uma incubação dessa mistura sobre as impressões de tecido por 2 horas a $37{ }^{\circ} \mathrm{C}$, permitiu otimizar a prova, levando a um aumento da intensidade de fluorescência e assegurando a completa inibição sobre os controles.

A desvantagem ocasionada pela demora na obtenção dos resultados devido aos tempos de incubação mais longos poderia ser questionada devido ao prolongamento do tempo de execução do teste. Entretanto, isso não se torna problema, uma vez que o tempo adicional dispendido nas incubações pode ser compensado pelo período mais curto de fixação das impressões em acetona. Conseqüentemente, se utilizada fixação em acetona por 30 minutos, otempo de duração da prova, desdea produção das lâminas até o exame das mesmas no microscópio, será de cerca de 4 horas, não havendo, em relação à técnica padrão, extensão do tempo total necessário para a obtenção do resultado final.
Algumas hipóteses sobre as razões que levaram a uma maior eficácia da prova modificada, podem ser conjeturadas. O período maior de incubação do conjugado sobre o material suspeito poderia permitir que um maior número de anticorpos viesse a ligar-se ao antígeno, aumentando assim a eficácia da reação. Coerente com isso, quanto mais longo o período de pré-adsorção com IMB, mais eficaz foi a inibição da fluorescência observada.

\section{CONCLUSÃO}

Os resultados demonstraram que a eficácia do teste de DFAT para diagnóstico de raiva pode ser aumentada substancialmente com o aumento dos períodos de incubação de préadsorção do conjugado e destes sobre as impressões, sem modificar a essência do teste. O conjugado pode ser utilizado mais diluido, levando a uma maior eficiência do reagente. A aplicação da metodologia aqui recomendada poderá contribuir para uma maior eficácia no uso dos reagentes para diagnóstico de raiva, bem como facilitar a leitura das lâminas.

\section{AGRADECIMENTO}

À Dra. Laura Pantoja,Fundação Estadual de Pesquisa e Produção em Saúde, Porto Alegre, RS, pela cedência da amostra CVS-31/2 obtida originalmente do INPPAZ.

\section{NOTAS INFORMATIVAS}

${ }^{1}$ INPPAZ - Instituto Panamericano de Protección de Alimentos y Zoonosis, Martínez, Argentina.

${ }^{2}$ Instituto de Tecnologia em Imunológicos, BioManguinhos. FIOCRUZ. Av. Brasil, 4365; C.E.P. 21045-000 - Manguinhos, Rio de Janeiro - RJ/Brasil. ${ }^{3}$ Carl Zeiss do Brasil LTDA. Santo Amaro. Av. Nações Unidas, 21711; C.E.P. 04795-100, São Paulo - SP/ Brasil. 


\section{REFERÊNCIAS}

1 Bourhy H., Kissi B. \& Tordo N. 1993. Taxonomy and evolutionary studies on Lyssaviruses with special reference to Africa. Ondersteeport Journal of Veterinary Research 60: 277-282,.

2 Dean D.J., Abelseth M.K. \& Atanasiu P. 1996. The fluorescent antibody test. In: Meslin F. X., Kaplan M.M. \& Koprowski H. (Eds). Laboratory Techniques in Rabies. 4th edn. Geneva: World Health Organization, pp. 88-95.

3 Koprowski H. 1996. The mouse inoculation test. In: Meslin F. X., Kaplan M.M. \& Koprowski H. (Eds). Laboratory Techniques in Rabies. 4th edn. Geneva: World Health Organization, pp. 80-86

4 Larghi O.P. 1971. Prueba de anticorpos fluorescentes para rabia. Nota Técnica ${ }^{\circ} 8$. Centro Panamericano de Zoonosis. Buenos Aires, 23 p.

5 Meslin F.X. \& Kaplan M.M. 1996. An overview of laboratory techniques in the diagnosis and prevention of rabies and rabies research. In: Meslin F. X., Kaplan M.M. \& Koprowski H. (Eds). Laboratory Techniques in Rabies. 4th edn. Geneva: World Health Organization, pp.157-174.

6 Sacramento D., Badrane H., Bourhy H. \& Tordo N. 1992. Molecular epidemiology of rabies virus in France: comparison with vaccine strains. Journal of General Virology. 73: 1149-1158.

7 Tordo N., Sacramento D. \& Bourhy H. 1996. The polymerase chain reaction (PCR) technique for diagnosis, typing and epidemiological studies of rabies. In: Meslin F. X., Kaplan M.M. \& Koprowski H. (Eds). Laboratory Techniques in Rabies. 4th edn. Geneva: World Health Organization, pp.157-174.

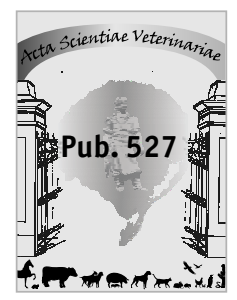

